\title{
THE IMPACT OF EXCHANGE RATE VOLATILITY ON EXPORT FLOWS IN DEVELOPING COUNTRIES
}

\author{
Oğuz TUMTURK ${ }^{1}$
}

\begin{abstract}
This article investigates the long run impacts of exchange rate volatilities on export volumes in six developing countries, Turkey, Indonesia, Brazil, Mexico, Poland, and Chile. The exchange rate volatility is estimated by both $\mathrm{ARCH} / \mathrm{GARCH}$ and moving sample standard deviation-based volatility proxies. Error correction representation of the long run export model reveals that there is not cointegration relationship for Brazil, Indonesia, and Chile while the results support the cointegration relationship for Turkey, Mexico, and Poland. Second, world income is major determinant driving export volumes in Turkey, Mexico, and Poland. Third, there is a significant negative relationship between exchange rate level and export volumes in Turkey and Mexico in line with theory. Finally, the measure of exchange rate volatility carries a significant negative coefficient in the case of Poland but a significant positive coefficient in the case of Turkey.
\end{abstract}

Jel Codes: F14, F31

Keywords: Real exchange rate, exchange rate volatility, export, long run equilibrium

\section{DÖVIZ KURU OYNAKLIĞININ GELIŞMEKTE OLAN ÜLKE IHRACAT AKIMLARINA ETKISI}

Öz

Bu çalışma döviz kuru oynaklığının ihracat akımları üzerindeki uzun dönem etkisini Türkiye, Endonezya, Brezilya, Meksika, Polonya ve Şili gelişmekte olan ülkeleri özelinde incelemektedir. Döviz kuru oynaklığı, hem ARCH/GARCH modeli hem de hareketli standart sapmalar bazlı ölçümlerle elde edilmiştir. Hata düzeltme modeli sonuçları Brezilya, Endonezya ve Şili özelinde bir eşbütünleşme ilşkisinin varlığını tespit edemezken diğer ülkelerde eşbütünleşme ilişkisi bulunmuştur. İkinci olarak, dış dünya gelir düzeyi Türkiye, Meksika ve Polonya'da ihracat akımlarını etkileyen en etkili değişkendir. Üçüncü olarak, Türkiye ve Meksika'da teorik beklentilere uygun şekilde reel döviz kuru düzeyi ile ihracat akımları arasında anlamlı negatif ilişkiler bulunmuştur. Son olarak ise, döviz kuru oynaklığı Polonya'da ihracat akımlarını olumsuz etkilerken, Türkiye'de ihracat üzerinde anlamlı pozitif ilişkiler üretmektedir.

JEL SInıflandırması: F14, F31

Anahtar Kelimeler: Reel Döviz Kuru, döviz kuru oynaklığı, ihracat, uzun dönem denge

${ }^{1}$ Dr. Öğr. Üyesi Ordu ÜniversitesiÜnye iktisadi ve Idari Bilimler Fakültesi ORCID: 0000-0002-1935-0858 


\section{Introduction}

Since the beginning of floating exchange rate regimes due to the collapse of the Bretton Woods System, exchange rates in many economies have started to fluctuate freely. Since then, uncertainty of the exchange rates and their impacts on different macroeconomic variables have emerged as one of the major research areas in economics. For instance, many empirical and theoretical studies have been published to reveal the link between "volatility of exchange rates" and "foreign trade volumes". Theoretically, the direct effect remained ambiguous, and direction of the impact was explained by the size of the "substitution and income effects" of the volatilities. This suggests that the direction of the link between volatility of exchange rate and trade volumes can only be resolved empirically. According to the large number of empirical studies, no general consensus has been reached on this matter, that is, volatility of exchange rate may produce either positive or negative impacts on trades. Investigation of the direction of the link is crucial for economies since policy-makers can derive different policy implications based on the country-specific evidences. For example, as pointed out by BahmaniOskooee and Gelan (2018), if volatility of exchange rate has an adverse effect on trade, a Central Bank often intervenes foreign exchange market to dampen the volatility and aims to increase trade flows. However, if exchange rate volatility has positive impacts on trade flows, then completely free exchange rates and no foreign market intervention will be quite efficient. As a result, what I do in this paper is to empirically reveal the link between volatility of exchange rates and exports.

This article investigates the long run impacts of exchange rate volatilities on export volumes for six developing countries, Turkey, Indonesia, Brazil, Mexico, Poland, and Chile ${ }^{2}$ using quarterly data by conducting autoregressive distributed lag (ARDL) model and error correction representation (ECM). The volatilities of many financial times series including exchange rates are not constant over time, and $\mathrm{ARCH} / \mathrm{GARCH}$ models allows volatility to vary through time. However, when exchange rate data do not provide ARCH effects, the exchange rate volatility measure will be substituted by another volatility measure, moving sample standard deviation. Hence, the main contribution of this study is to employ both ARCH/GARCH and moving sample standard deviation-based measures together when modeling directly unobservable exchange rate volatilities in developing countries. Finally, long run estimates of the export function are produced from ARDL-bound testing approach and error correction representation based on these two volatility proxies.

The remainder of the chapter is as follows. Section 2 explains the theoretical link between exchange rate volatility and export volumes. In Section 3, I present a brief overview of the empirical literature. Section 4 includes model specification and selected econometric method while data and empirical results are reported in Section 5. Finally, summary and conclusion are drawn in Section 6.

\section{Theory: Effects of Real Exchange Rate Volatility on Export Volumes}

In general, the theoretical link between volatility of exchange rates and export volumes can be explained by size of the "income and substitution effects". Regarding the impacts of exchange rate volatility and trade volumes, one of the leading theoretical analyses has been outlined by Hooper and Kohlhagen (1978) under the theory of uncertainty. They argue that if exporters are risk averse then elevated volatility in exchange rate is expected to reduce export flows. As explained by Arize, Osang, and Slottje (2000), exchange rate is determined by the exporter and importer at the time of trade contract. However, exporters do not receive their payments until the exported goods and services are delivered. Under the existence of high volatility, unpredictable exchange rates produce uncertainty about the future earnings and discourage exporters from selling their products abroad. This negative

\footnotetext{
2 Detailed information on the classification of developing countries can be found in the International Monetary Fund's World
} Economic Outlook (2018, pp. 134-135). 
impact on trade volumes explains the "substitution effect" of volatility of exchange rates on trade. However, Ethier (1973) and Baron (1976) argue that if the forward markets are available and hedging is possible, exchange rate uncertainty does not produce any impact on trade flows. Viaene and DeVries (1992), on the other hand, point out that if the hedging is difficult and expensive, uncertainty has indirect impact on trade volumes, and substitution effect is still valid.

Another possible impact of the volatility of exchange rate on trade volumes is explained by "income effect". According to the income effect, if exporters are risk averse, a higher volatility elevates the expected marginal utility of export revenue as a result of quick and massive decline of export volumes driven by substitution effect. Then, increasing marginal utility of export revenue stimulates exporters to increase their products that they sell abroad. This effect is known as "income effect" of the volatility of exchange rates on export flows. Consequently, the net effect is determined by the sum of the magnitude of the income and substitution effects. Based on the net impact, exchange rate volatility may produce either a positive or a negative impact on export volumes.

\section{Literature}

One of the very first paper to explore the relationship between exchange rate volatility and trade is published by Hooper and Kohlhagen (1978). They analyze the exchange rate uncertainty on prices and trade between U.S. and Germany over the period of 1965-1975. Hooper and Kohlhagen conclude that exchange rate uncertainty produces significant impact on prices while results does not confirm the link between uncertainty and trade volumes. Chowdhury (1993) studies the impact of exchange rate volatility on the trade flows of the G-7 countries. He reveals the negative impacts of exchange rate volatility on export volumes in each of the seven countries. He also asserts that previous studies consistently find quite weak relationship between trade volumes and volatility since these studies do not take into account the stochastic properties of the relevant time series. Franke (1991) argues that elevated exchange rate volatility might increase the trade level of exporting firms. He also presents some conditions that exchange rate volatility stimulates the volume of international trade. Similarly, De Grauwe (1988), Dellas and Zilberfarb (1993) support the argument that volatility may increase the volume of trade while Gagnon (1993) and Wolf (1995) suggest that volatility dampens the trade volumes.

Arize, Osang, and Slottje (2000) use Johansen's cointegration approach for 13 less developed countries, and their results suggest that volatility significantly reduces the export volumes in each of the 13 countries. Doroodian (1999) studies the influences of exchange rate volatility on trade volumes for developing countries, over the period of 1973 and 1996 by employing ARMA and GARCH models. He concludes that uncertainty on exchange rate significantly reduce trade volumes. Doganlar (2002) investigates the impacts of exchange rate volatility for Turkey, South Korea, Malaysia, Indonesia and Pakistan by using Engle-Granger cointegration approach. The result presents that exchange rate volatility significantly reduces the export volumes. Wang and Barrett (2007) investigate the impact of exchange rate volatility on Taiwan's exports to the U.S. between 1989-1998 by using multivariate GARCH-M estimator. They find that change in either importing country production or expected exchange rate are the main determinants of trade flows. Additionally, they claim that exchange rate volatility only influences the agricultural trade volumes. Asteriou, Masatci and Pilbeam (2016) employ GARCH-based volatility measure in the ARDL error correction representation for Mexico, Indonesia, Nigeria, and Turkey. They find no relationship between volatility and foreign trade except for Turkey in the long run. Arize, Osang, and Slottje (2008) use several cointegration techniques over the period of 1973-2004 for the eight Latin American countries, and suggest that increase in exchange rate volatility significantly decreases export flows in the long run. Hall, Hondroyiannis, Swamy, Tavlas and Ulan (2010) show that there is not a negative and significant relationship between Emerging Market Economies

\section{Uluslararası İktisadi ve İdari İncelemeler Dergisi}


exchange-rate volatility and exports flows for the period between 1980 and 2006. Additionally, they conclude that open capital markets might be a major factor reducing the negative impact of volatility on trades.

Houchet-Bourdon and Korinek (2011) investigate the relationship between volatility and trade flows in China, the Euro area and the United States by using ARDL bound test and error correction representation. They find that volatility weakly affects trade. Additionally, the impact of exchange rates on exports of agricultural goods relatively greater than manufacturing goods. Finally, exchange rate volatility does not present a strong evidence to stimulate bilateral trade flows. Bahmani-Oskooee and Gelan (2018) study the exchange rate volatility and trade relationship for the twelve African countries. They find evidence that volatility produces significantly negative impact on export demand in two countries and positive impacts on three countries. They also state that major component which triggers export volumes is world income. Baum and Caglayan (2010) analyze the industrialized countries for the time period 1980-2006, and conclude that volatility of exchange rate produces a significantly positive impact on the volatility of bilateral trade volumes. However, exchange rate volatility does not exert a significant effect on the level of the trade volumes.

\section{Model Specification and Econometric Method}

With regard to modelling the impact of the level of exchange rates and their volatility on export demands in developing countries, I follow a traditional long-run equilibrium export model proposed by Arize (1995) and Chowdhury (1993). This model depends upon the flexible exchange-rates both in terms of level and volatility and world income. Long run export volume are formulated as follows:

$\log X_{t}=b_{0}+b_{1} \log W_{t}+b_{2} \log R E R_{t}+b_{3} V L_{t}+\omega_{t}$

where $X_{t}$ is a country's real exports, $W_{t}$, is real world income, $R E R_{t}$ is relative prices, i.e. real effective exchange-rate, and $V O L_{t}$ is the exchange rate volatility. $\omega_{t}$ is, on the other hand, a disturbance term. If the real world income raises, it should stimulate more exports; hence, its sign is expected to become positive, i.e. $b_{1}>0$. As a decrease in exchange rate represents a real depreciation of home currency, $R E R_{t}$ variable should carry negative sign, i.e. $b_{2}<0$. Finally, since the impacts of exchange rate volatility on export is uncertain in literature, an estimate of $b_{3}$ can reveal either a negative or positive sign. Finally, all variables in equation (1) are expressed in logarithmic form.

In this study, I follow the ARDL-bound testing approach proposed by Pesaran and Shin (1998) and Pesaran, Shin, and Smith (2001) and error correction representation. Equation (1) is reformulated as the ECM form in equation (2):

$$
\begin{gathered}
\Delta \mathrm{X}_{\mathrm{t}}=\mathrm{d}_{0}+\alpha E C M_{\mathrm{t}-1}+\sum_{\mathrm{i}=1}^{\mathrm{p}} \mathrm{d}_{\mathrm{i}}^{\mathrm{X}} \Delta \mathrm{X}_{\mathrm{t}-\mathrm{i}}+\sum_{\mathrm{i}=0}^{\mathrm{q} 1} \mathrm{~d}_{\mathrm{i}}^{\mathrm{W}} \Delta \mathrm{W}_{\mathrm{t}-\mathrm{i}}+\sum_{\mathrm{i}=0}^{\mathrm{q} 2} \mathrm{~d}_{\mathrm{i}}^{\mathrm{RER}} \Delta \mathrm{RER}_{\mathrm{t}-\mathrm{i}}+\sum_{\mathrm{i}=0}^{\mathrm{q} 3} \mathrm{~d}_{\mathrm{i}}^{\mathrm{VOL}} \Delta \mathrm{VOL}_{\mathrm{t}-\mathrm{i}}+\mathrm{u}_{\mathrm{t}} \\
E_{\mathrm{t}-1}=\theta_{1} \mathrm{X}_{\mathrm{t}-1}-\theta_{2} \mathrm{~W}_{\mathrm{t}-1}-\theta 3 \mathrm{RER}_{\mathrm{t}-1}-\theta_{4} \text { VOL }_{\mathrm{t}-1}
\end{gathered}
$$

where $\alpha$ is speed of adjustment coefficient. The lagged level variables $\theta_{2}, \theta_{3}$, and $\theta_{4}$ are normalized on $\theta_{1}$, and determine the long run effects the export model ${ }^{3}$. The optimal lag orders $p, q_{1}, q_{2}$ and $q_{3}$ can be specified by the Schwarz-Bayesian (1978) (SBIC) or the Akaike (1973) information criterions (AIC). According to the ECM, if the current amount of the export is not equal to the fundamental value or

\footnotetext{
${ }^{3}$ Error correction representation in (2) also gives short run effects of exogeneous variables on exports, i.e. $d_{i}^{W}, d_{i}^{R E R}, d_{i}^{V O L}$; however, in many studies, either the results are statistically insignificant or estimated statistically significant coefficients carry an incorrect sign. As a result, many studies conclude that short-run effects do not track any pattern (Baek and Koo (2009), BahmaniOskooee and Gelan (2018), Huchet-Bourdon and Korinek (2011), Bahmani-Oskooee and Ratha (2004), Simsek and Kadilar (2006). Additionally, exporters can eliminate the exchange rate risk in short run easily as hedging in short run is not costly relative to long run (Perée and Steinherr (1989)). Consequently, the literature pays much more attention to the long run impacts of exchange rate volatility on trade volumes.
} 
long run amount of the export volume, then current export will adjust itself toward long run equilibrium level by the rate of speed of adjustment coefficient. Therefore, any deviation from the long run will correct itself through time.

ARDL model is being used for decades, and has some practical advantages for the researchers. First, ARDL model has a reparameterization in the form of error correction representation, and the presence of cointegrating relationship can be analyzed based on the error correction form. Second, ARDL model does not necessitate to identify that whether the variables of interest are integrated of order zero or one, i.e. I(0) or I(1), respectively unlike the conventional cointegration methods ${ }^{4}$. Hence, I(0) or I(1) variables can be employed in a same estimation. Third, unlike the conventional methods such as Johansen (1988) maximum likelihood which determines the cointegration relationship in a system equations, ARDL method uses a single equation time series form. Fourth, ARDL model produces more efficient estimators when the sample length is not very large. Finally, the inclusion of short term dynamics in the form of lagged-differenced series in the ARDL model may handle possible endogeneity and serial correlation problems ${ }^{5}$.

To verify the existence of a cointegration relationship, the conventional $\mathrm{F}$ test for joint significance of lagged-level variables is conducted. The equation (2) is first estimated by using ordinary least square (OLS), and the null hypothesis of no cointegration, i.e. $H_{0}: \theta_{1}=\theta_{2}=\theta_{3}=\theta_{4}=0$, is tested by using $F$ test against alternative hyphothesis, i.e. $H_{0}: \theta_{1} \neq \theta_{2} \neq \theta_{3} \neq \theta_{4} \neq 0$. Since the conventional $\mathrm{F}$ test is inapplicable in the context of ARDL approach, Pesaran et al. (2001) tabulates two distinct critical values which are called upper and lower bound limits. According to the ARDL-bound testing approach, cointegration exists if the computed $F$ statistic exceeds the upper bound limit. If the calculated $F$ statistic less than the lower bound limit, then one cannot reject the the null hyphothesis of no cointegration. Finally, if the calculated F statistic takes a value inside the upper and lower bounds, then the test does not conclude.

After detecting the existence of a cointegrating relationship in the ECM form of the export model (2), the long run coefficients of the model can be estimated. A negative and significant speed of adjustment coefficient $(\alpha)$ confirms the equilibrium relationship and present another hint for the existence of cointegration relationship among variables. Finally, the post estimation diagnostics are generated to establish how the export model (2) fits the data. These diagnostic tests are Ramsey Reset Test for confirming the linear specification of the model against nonlinear specification proposed by Ramsey (1969), and Breusch-Godfrey Lagrange Multiplier Test for testing serial correlation free residuals, and White (1980) test for heteroscedasticity.

\subsection{Measurement of Exchange Rate Volatility}

Although there are large number of studies investigating the impact of exchange rate volatility on various macroeconomic variables, there is still no consensus on what is the best measure of "volatility" ${ }^{6}$. In this article, I use two broadly used distinct proxies to measure exchange-rate volatility.

\footnotetext{
${ }^{4}$ Engle and Granger (1987) two-step process and Johansen (1988) maximum likelihood approach are known as the conventional cointegration methods in literature and both require to determine the integrated of orders of the variables before the estimation process. The standard statistical inference based on these methods are depends on the argument that all variables are integrated of order one. Additionally, general pretesting problems such as misclassification of variables as I(0) or I(1) may lead researchers to conclude incorrect statements about time series feature of the data (Kripfganz and Schneider (2016)).

${ }^{5}$ In the error correction model (2), several instrumental variables proposed by Pagan and Ullah (1988) are used under the assumption of endogeneity of some of the explanatory variables. These instrumental variables are constant coefficient, the lagged error correction term (ECM $\left.\mathrm{t}_{\mathrm{t}-1}\right)$, and explanatory variables with a number of lagged-differences.

"Some of the example of these distinct measures are "standard deviation of the first difference of the log exchange rates", "moving sample standard deviation measure of the log exchange rates", and "conditional volatility measure estimated from
} 
First measure is known as the conditional volatility of exchange rates estimated from a generalized autoregressive conditional heteroscedasticity (GARCH) model proposed by Bollerslev (1986). Timedependent volatility of the exchange rate as a function of observed prior volatility is broadly estimated by ARCH models proposed by Engel (1982). Later, Bollerslev extended ARCH models to a GARCH model by adding lagged values of the conditional variance. GARCH models and their extensions were empirically considered quite successful in modelling volatility clustering feature of the exchange rate data. Volatility clustering is first stated by Mandelbrot (1963), and it represents the fact that large changes are tend to be followed by large changes and small changes are tend to be followed by a small change ${ }^{7}$. A general $\mathrm{GARCH}(\mathrm{m} ; \mathrm{k})$ process for exchange rate is written as:

$$
\begin{gathered}
\Delta \text { RER }_{\mathrm{t}}=\omega+\varepsilon_{\mathrm{t}} \\
\sigma_{\mathrm{t}}^{2}=\gamma_{\mathrm{c}}+\gamma_{1} \varepsilon_{\mathrm{t}-1}^{2}+\gamma_{2} \varepsilon_{\mathrm{t}-2}^{2}+\cdots+\gamma_{\mathrm{m}} \varepsilon_{\mathrm{t}-\mathrm{m}}^{2}+\zeta_{1} \sigma_{\mathrm{t}-1}^{2}+\zeta_{2} \sigma_{\mathrm{t}-2}^{2}+\cdots+\zeta_{\mathrm{m}} \sigma_{\mathrm{t}-\mathrm{k}}^{2} \\
\varepsilon_{\mathrm{t}} \sim \operatorname{GED}\left(0, \sigma_{\mathrm{t}}^{2}, \rho\right)
\end{gathered}
$$

Where $\varepsilon_{\mathrm{t}}$ is disturbance term, $\omega$ is a constant and $\gamma_{i}$ are the ARCH parameters and $\zeta_{\mathrm{i}}$ are the GARCH parameters. $\mathrm{GARCH}(\mathrm{m} ; \mathrm{k})$ model contains the combination of conditional mean equation (3) and conditional variance equation (4). As seen in equation (4), m-lagged values of squared disturbances and k-lagged values of conditional variances form the current conditional variance $\left(\sigma_{t}^{2}\right)$ of the regression (3) disturbances. The conditional distribution of the disturbance term has a vital role when estimating the GARCH models. When estimating the model, I employ Generalized Error Distribution (GED) Distribution with shape parameter $\rho$ since the distribution of the most of the financial time series in practice are leptokurtic, i.e. extreme values are more frequent than normally distributed series. The GED distribution with shape parameter smaller than two has fatter tails; hence, it asymptotically converges to zero more slowly than Gaussian normal ${ }^{8}$. In this study, conditional volatility is measured by equation (4). Finally, the optimal lags of equation (4) is determined by likelihood ratio test.

Second measure, on the other hand, is known as moving sample standard deviation (MSSD) of volatility expressed in the form of:

$\operatorname{VOL}_{\mathrm{t}}=\left[(1 / \mathrm{p}) \sum_{\mathrm{i}=1}^{\mathrm{k}}\left(\mathrm{RER}_{\mathrm{t}+\mathrm{i}-1}-\mathrm{RER}_{\mathrm{t}+\mathrm{i}-2}\right)^{2}\right]^{1 / 2}$

where $\mathrm{p}$ is the order of moving average ${ }^{9}$. Whenever exchange rate data do not exhibit ARCH effects then I use conditional volatility equation (5) instead of (4).

\section{Data and Empirical Results}

\subsection{Data}

The data used are quarterly for the sample period 1998:Q1-2017:Q1 for Turkey; 1996:Q1-2017:Q1 for Mexico; 2000:Q1-2017:Q1 for Indonesia; 1996:Q1-2017:Q1 for Brazil; 2002:Q1-2017:Q1 for Poland;

ARCH/GARCH models". For a detailed information for distinct measures, see Mckenzie (1998), Huchet-Bourdon and Korinek (2011), Arize et al (2000), Nicita (2013), Sauer and Bohara (2001), Hall et al.(2010)

${ }^{7}$ For example, Pozo (1992), Dorodian (1999), Wang and Barrett (2007), Rahmatsyah, Rajaguru, and Siregar (2002), Hall et al. (2010), Kroner and Lastrapess (1993), McKenzie and Brooks (1997), Mckenzie (1998) have used ARCH/GARCH-based measure of volatility.

${ }^{8}$ Other distributions having fatter tails than Gaussian normal distribution are Laplace and Student-t distributions.

${ }^{9} \mathrm{I}$ employ the eight-quarter moving standard deviation of the log real effective exchange rate in this study. This measure is quite standard in much of the literature (e.g. Arize et al (2000), Sauer and Bohara (2001), Arize, Malindretos, and Kasibhatla (2003), Rey (2006), Hall et al. (2010), Bahmani-Oskooee and Gelan (2018), Chowdhury (1993), Kenan and Rodrik (1986), Doganlar (2002)). 
and 2000:Q1-2017:Q1 for Chile based on the data avilability. All data are represented in real terms and obtained from Federal Reserve Bank of St. Louis and the Central Bank of the Republic of Turkey ${ }^{10}$.

\subsection{Empirical Results}

After differencing the log exchange rate to correct for nonstationarity ${ }^{11}$, one can present the descriptive summary statistics for the log-differenced exchange rate series. Table 1 shows that all series exhibit the usual features of GARCH models such as excess kurtosis (or leptokurtic distribution) and negative skewness ${ }^{12}$. While Shapiro-Wilk (1965) W test for normality reveals that log-differenced series are not normally distributed at ten percent significance level each of the six countries. Moreover, Engle's (1982) Lagrange multiplier test (ARCH-LM Test) results confirm the presence of autoregressive conditional heteroskedasticity in the results for Turkey, Indonesia and Poland at ten percent significance level. As stated by Westerfield (1977) and Hsieh (1989), leptokurtic exchange rate differences suggest volatility clustering, and GARCH-based models are the quite convenient for modelling the volatility clustering feature of the financial time series. As a result, all these preliminary results suggest that GARCH models are best fit for the exchange rate volatility for Turkey, Indonesia and Poland. On the other hand, I choose the moving sample standard deviation as a measure of volatility of exchange rate over the GARCH-based volatilities for Brazil, Mexico and Chile data since ARCH-LM tests for these countries do not exhibit ARCH effects on the log-differenced exchange rate data. Now, one can further estimate the conditional variance equation (4) for Turkey, Indonesia and Poland.

Table 1: Descriptive Statistics on Log-Differenced RER

\begin{tabular}{|c|c|c|c|c|c|c|}
\hline & Turkey & Indonesia & Brazil & Mexico & Poland & Chile \\
\hline Skewness & -0.232 & -1.979 & -1.81 & -0.709 & -1.375 & -0.482 \\
\hline Kurtosis & 4.432 & 11.66 & 9.227 & 4.77 & 6.306 & 3.504 \\
\hline $\begin{array}{l}\text { Shapiro-Wilk W } \\
\text { Test statistics }^{\text {a }}\end{array}$ & $0.97 * * *$ & $0.823^{*}$ & $0.866^{*}$ & $0.960 * *$ & $0.896^{*}$ & $0.977 * * *$ \\
\hline $\begin{array}{c}\text { ARCH-LM } \\
\text { Test Statistics }^{b}\end{array}$ & $6.568^{*}$ & $3.333^{* * *}$ & 0.07 & 0.990 & $10.394^{*}$ & 0.589 \\
\hline
\end{tabular}

Note: ${ }^{* *}$, Significance at $10 \%$; $* *$, significance at $5 \%$; ${ }^{*}$, significance at $1 \%$.

a Null hyphothesis Shapiro-Wilk (1965) W Test is "data are normally distributed".

b Null hyphothesis for the Engle's (1982) ARCH-LM test is "No ARCH effect".

The model of choice to measure exchange rate volatility in this study is the ARCH(1) for Turkey; $\operatorname{GARCH}(1,1)$ for Indonesia; and $\operatorname{GARCH}(1,2)$ for Poland based on the likelihood ratio test ${ }^{13}$. Table 2 summarizes the results obtained from conditional variance equation (4) and presents several

\footnotetext{
${ }^{10}$ For detailed data definitions and data sources, see Appendix A, Table A.1.

${ }^{11}$ Augmented Dickey Fuller (1979) (ADF) and Phillips-Perron (1988) unit root test results for log real effective exchange rate are reported in Appendix A. The results are given based on three distinct cases: trend and constant, constant, and none.

${ }^{12}$ A distribution with excess kurtosis implies that tails are fatter than normal distribution; therefore, such a distribution produces more outliers than the normal distribution. If a calculated kurtosis for a distribution is above 3 , then the distribution is said to be "leptokurtic". Negative skewness implies that a distribution has more extreme measurements in the left tail than right tail.

${ }^{13}$ One can argue that the sample periods are not large enough for $A R C H / G A R C H$ volatility estimates. However, several studies in the literature employ similar sample sizes when estimating exchange rate volatilities. For example, Arize (1995), Hall et al. (2010), Doroodian (1999), Crowley and Lee (2003) and Rahmatysah et al. (2002) use quarterly data for the sample lengths varying between 18 and 26 years
} 
regression diagnostics. $\lambda$ represents the number of iterations that log-likelihood convergence is achieved while In $\mathrm{L}$ denotes the value of the log-likelihood function. All three estimated shape parameters are less than two which implies that the distributions of the disturbances have fatter tails than normally distributed disturbances, as expected. This also indicates that the choice of GARCH with GED distribution over the GARCH with Gaussian normal appears to be quite reasonable. Finally, ARCHLM test reveals that one cannot reject the null of no ARCH effects in the standardized residuals, and the data for Turkey, Indonesia, and Poland fit the model very well.

Table 2: GARCH Estimations, Conditional Volatility of RER

\begin{tabular}{cccc}
\hline & Turkey & Indonesia & Poland \\
\hline ARCH(1) & $0.593^{* * *}$ & $1.405^{*}$ & $0.593^{* *}$ \\
ARCH(2) & & \\
GARCH(1) & & $0.159 * * *$ & \\
GARCH(2) & & $-0.273^{*}$ \\
$\boldsymbol{\lambda}$ & 9 & 39 & 18 \\
In L & 173.766 & 146.99 & 172.604 \\
$\mathbf{P}$ & 1.115 & 1.750 & 1.859 \\
ARCH LM & 0.019 & 1.492 & 2.123 \\
Test Stat. & &
\end{tabular}

Table 3: ARDL Bound Test and Several Diagnostics

\begin{tabular}{|c|c|c|c|c|c|c|}
\hline & Turkey & Mexico & Indonesia & Brazil & Poland & Chile \\
\hline $\begin{array}{l}\text { Volatility } \\
\text { Measure }\end{array}$ & $\mathrm{ARCH}(1)$ & MSSD & $\operatorname{GARCH}(1,1)$ & MSSD & GARCH $(1,2)$ & MSSD \\
\hline $\begin{array}{l}\text { Speed of } \\
\text { Adjustment } \\
\text { Coefficient }(\alpha)\end{array}$ & $-0.690 *$ & $-0.259 *$ & $-0.307^{*}$ & -0.097 & $-0.433^{*}$ & -0.050 \\
\hline F Statistics ${ }^{a}$ & $12.327^{*}$ & $9.607^{*}$ & 3.270 & 2.070 & $9.656^{*}$ & 1.698 \\
\hline $\begin{array}{l}\text { Breusch- } \quad I=1 \\
\text { Godfrey }\end{array}$ & 0.006 & 0.014 & 1.038 & 3.180 & 2.865 & 0.790 \\
\hline $\begin{array}{l}\text { LM Test } \\
\text { Statistic }^{\text {b }}\end{array}$ & 2.001 & 1.291 & 5.610 & 3.852 & 3.495 & 4.543 \\
\hline $\begin{array}{l}\text { Ramsey's Reset } \\
\text { Test Statistic }\end{array}$ & 1.30 & 0.16 & 2.01 & 1.46 & 1.69 & 0.26 \\
\hline $\begin{array}{l}\text { White Test } \\
\text { Statistics }^{d}\end{array}$ & 69.20 & 66.85 & 16.03 & 46.68 & 1.61 & 33.84 \\
\hline
\end{tabular}


${ }^{a}$ Lower and critical upper critical values for $\mathrm{F}$ test are 5.17 and 6.36 at one percent significance level, 4.01 and 5.07 at five percent significance level, and 3.47 and 4.45 at ten percent significance level respectively. All models include unrestricted constant and trend. Null hypothesis indicates no cointegration relationship.

b Null hyphotesis of the Breusch-Godfrey LM test is "no serial correlation". Test statistics are given for two different lags, $\mathrm{l}=1$ and $\mathrm{l}=4$.

"Null hyphothesis of the Ramsey's (1969) Reset test is "No functional form specification".

'Null hyphothesis of the White's (1980) Test for heteroscedasticity is "residuals have constant variance."

Given the presence of the real effective exchange rate volatilities obtained from either GARCH or MSSD based calculations in the error correction model (2), Table 3 presents the ARDL-bound testing results and several diagnostics. When estimating an ARDL model, all statistical results are sensitive to violation of classical assumptions on disturbance term. As seen in Table 3, bound test results justify the cointegration relationship in the results for Turkey, Mexico, and Poland since F-values are greater than the upper critical value. Additionally, both significant and negative $\alpha$ coefficients for these countries indicate the adjustment toward long run equilibrium and presents another evidence that cointegration relationships are valid. If a shock appears in short run, the estimated $\alpha$ coefficient obtained from Turkey's export model concludes that about 70 percent of the deviation from the long run equilibrium corrects itself in one quarter. This rate is $26 \%$ and $43 \%$ for Indonesia and Poland, respectively. Finally, ARDL-bound testing results, on the other hand, do not confirm the validity of cointegration relationship for Indonesia, Brazil, and Chile since F-values fall below the lower bounds. To confirm whether or not the findings obtained from error correction form of the export model in Table (3) are valid, one should conduct diagnostic tests. First, Breusch-Pagan test result exhibits that null hypothesis of no serial correlation cannot be rejected for each of the six countries, and residuals are free from serial correlation. Second, Ramsey's Reset Test (1969) reveals that F statistic is lower than the critical value indicating that there is not a functional form misspecification, i.e. non-linear combinations of the explanatory variables cannot explain the export variable. Finally, White (1980) test results shows that one cannot reject the null of constant variances for each of the six countries. Consequently, all diagnostic tests provide support for the ARDL error correction representation, and the statistical fit of the model to the data is quite reasonable.

Table 4: Long-Run ECM Estimates

\begin{tabular}{clll}
\hline $\begin{array}{c}\text { Long Run Estimates } \\
\text { (P-value) }\end{array}$ & Turkey & Mexico & Poland \\
\hline W & $2.874^{*}$ & $0.800^{* * *}$ & $1.07^{* *}$ \\
RER & $-0.454^{*}$ & $-0.633^{*}$ & 0.097 \\
VOL & $0.127^{* * *}$ & 0.281 & $-0.173^{*}$ \\
\hline
\end{tabular}

Note: ${ }^{* * *}$, Significance at $10 \% ; * *$, significance at $5 \% ; *$, significance at $1 \%$.

Long run estimates obtained from error correction form of exports (2) for the countries Turkey, Mexico, and Poland are shown in Table 4. According to long run estimates of the export models, the exchange rate volatility variable carries significant negative sign for Poland indicating that volatility of exchange rates lowers the export volumes. However, volatility variable has positive significant impact on real exports at ten percent significance level for Turkey. These positive and negative signs are again in line with theoretical expectations explained by "income and substitution effects" of export volumes. Second, the coefficient of the real effective exchange rate is statistically significant and negative for both Turkey and Mexico, i.e. depreciation of real effective exchange rate boosts export volumes in the long run. Finally, an increase in world income stimulates the export significantly for all three countries 
as theory predicted. In other words, the results confirm the broadly accepted argument in literature that world income is the strongest determinant of a country's export.

\section{Summary and Conclusions}

This study investigates the export volumes of six developing countries as a function of exchange rate volatility, level of exchange rates and world income using quarterly data. Deriving the impact of exchange rate volatility on trade is first step to require to measure exchange rate volatility. There are several measures in finance literature, and I employed two of them in this study together. If exchange rate data exhibit usual features of $\mathrm{GARCH}$ models, such as leptokurtic distribution and negative skewness in addition to the presence of autoregressive conditional heteroskedasticity, GARCH-based proxy of exchange rate volatility may be quite reasonable. However, under the non-existence of $A R C H$ effects, I use another measure of volatility, moving sample standard deviation. After measuring the exchange rate volatility with both GARCH and moving sample standard deviation-based proxies, ARDLbound testing approach and error correction representation had been conducted, and long run estimations were produced.

The empirical and theoretical literature suggest that volatility of exchange rates can produce either positive or negative outcome on trade based on the magnitude of "income" or "substitution" effects. Conversely, the impact of level of exchange rate and world income on trade volumes are quite predictable. The empirical results presented in this study first reveal that there is not cointegration relationship for Brazil, Indonesia, and Chile which means that any short run deviation from the long run equilibrium level of export volumes will not correct itself over time. On the other hand, the results support the cointegration relationship for other countries, Turkey, Mexico, and Poland. Second, world income is major determinant driving export volumes in line with previous empirical studies. Third, there is a significant negative relationship between exchange rate level and export volumes for Turkey and Mexico as theory predicted. Finally, the measure of exchange rate volatility carries a significant negative coefficient in the case of Poland while there is a significant positive relationship between volatility and exports in the case of Turkey. Hence, the empirical results obtained in this study regarding with the impact of volatility of exchange rate and trade are in line with previous studies in the literature.

This study also presents some opportunities for future research. First, the results of the study can be expanded by specific trade sectors, e.g. agriculture, mining, manufacturing, energy etc. Therefore, one can evaluate the impacts of volatility of exchange rates on specific trade sectors. Second, while the exchange rate literature mostly focusses on export volumes, there are only a few studies studying exchange rate volatility on import volumes. Hence, long run import model can be estimated by the same estimation procedure conducted in this study for the case of developing countries.

\section{References}

Akaike, H. (1973). Information Theory and an Extension of the Maximum Likelihood Principle. Second International Symposium on Information Theory, Budapest: Academiai Kiado.

Arize, A. C. (1995). The Effects of Exchange-rate Volatility on U.S. Exports: An Empirical Investigation, Southern Economic Journal, 62(1), 34-43.

Arize, A.C., Malindretos, J. and Kasibhatla, K.M. (2003). Does Exchange Rate Volatility Depress Flows: The Case of LDCs. International Advances in Economic Research, 9(1), 7-19.

Arize, A.C., Osang, T. and Slottje D.J. (2000). Exchange- Rate Volatility and Foreign Trade: Evidence From Thirteen LDCs. Journal of Business \& Economic Statistics, 18:1, 10-17. 
Arize, A.C., Osang, T. and Slottje D.J. (2008). Exchange-rate Volatility in Latin America and Its Impact on Foreign Trade. International Review of Economics and Finance, 17(1), 33-44.

Asteriou, D., Masatci, K. and Pilbeam, K. (2016). Exchange Rate Volatility and International Trade: International Evidence from the MINT Countries. Economic Modelling, 58, 133-140.

Baek, J., Koo Won, W. (2009). Assessing the Exchange Rate Sensitivity of US Bilateral Agriculture Trade. Canadian Journal of Agriculture Economics, 57, p. 187-203.

Bahmani-Oskooee, M. and Gelan, A. (2018). Exchange-rate Volatility and International Trade Performance: Evidence from 12 African Countries. Economic Analysis and Policy, 58, 14-21.

Bahmani-Oskooee, M. and Ratha, A. (2004). Dynamics of the US Trade with Developing Countries. Journal of Developing Areas, 37(2), 1-11.

Baron, D.P. (1976). Fluctuating Exchange Rates and Pricing of Exports, Economic Inquiry, 14(3), 425-38

Baum, C.F. and Caglayan, M. (2010). On the Sensitivity of the Volume and Volatility of Bilateral Trade Flows to Exchange Rate Uncertainty. Journal of International Money and Finance, 29(1), 7993.

Bollerslev, T. (1986). Generalized Autoregressive Conditional Heteroscedasticity. Journal of Econometrics, 31, 307-32.

Chowdhury, A. R. (1993). Does Exchange Rate Volatility Depress Trade Flows? Evidence from ErrorCorrection Model. Review of Economics and Statistics, 75(4), 700-706.

Crowley, P. and Lee, J. (2003) Exchange Rate Volatility and Foreign Investment: International Evidence. The International Trade Journal, 17(3), 227-252

De Grauwe, P. (1988). Exchange Rate Variability and the Slowdown in Growth of International Trade, IMF Staff Papers, 35(1), 63-84

Dellas, H. and Zilberfarb, B.Z. (1993). Real Exchange Rate Volatility and International Trade: A ReExamination of the Theory. Southern Economic Journal, 59(4), 64-647.

Dickey, D.A. and Fuller, W.A. (1979). Distribution of the Estimators for Autoregressive Time Series with a Unit Root. Journal of the American Statistical Association, 74, 427-431.

Doganlar, M. (2002). Estimating the Impact of Exchange Rate Volatility on Exports Evidence from Asian Countries. Applied Economics Letters, 9, 859-863.

Doroodian, K. (1999). Does Exchange Rate Volatility Deter International Trade in Developing Countries? Journal of Asian Economics, 10, 465-474.

Ethier, W. (1973). International Trade and the Forward Exchange Market. The American Economic Review, 63(3), 494-503.

Engle, R.F. (1982). Autoregressive Conditional Heteroscedasticity with Estimates of the Variance of United Kingdom Inflation. Econometrica, 50(4), 987-1007.

Engle, R. F. and Granger, C.W.J. (1987). Co-integration and Error Correction: Representation, Estimation, and Testing. Econometrica, 55(2), 251-276.

Franke, G. (1991). Exchange Rate Volatility and International Trading Strategy. Journal of International Money and Finance, 10(2), 292-307. 
Gagnon, J.E. (1993). Exchange Rate Variability and the Level of International Trade. Journal of International Economics, 34, 269-287.

Hall, S., Hondroyiannis, G., Swamy, P.A.V.B., Tavlas, G. and Ulan, M. (2010). Exchange-Rate Volatility and Export Performance: Do Emerging Market Economies Resemble Industrial Countries or Other Developing Countries? Economic Modelling, 27, 1514-1521.

Hsieh, D. A. (1989). Modeling Heteroscedasticity in Daily Exchange Rates. Journal of Business and Economic Statistics, 7(3), 307-317.

Hooper, P. and Kohlhagen, S. W. (1978). The Effect of Exchange Rate Uncertainty on the Prices and Volume of International Trade. Journal of International Economics, 8, 483-511.

Huchet-Bourdon, M. and Korinek, J. (2011). To What Extent Do Exchange Rates and Their Volatility Affect Trade? OECD Trade Policy Papers, No. 119, OECD Publishing, Paris. http://dx.doi.org/10.1787/5kg3slm7b8hg-en

International Monetary Fund. (2018). World Economic Outlook: Challenges to Steady Growth. Washington,DC,October,https://www.imf.org/en/Publications/WEO/Issues/2018/09/24/wor Id-economic-outlook-october-2018. Retrieved 2018-09-26.

Johansen, S. (1988). Statistical Analysis of Cointegration Vectors. Journal of Economic Dynamics and Control, 12(2-3), 231-254

Kenan, P. T. and Rodrik, D. (1986). Measuring and Analyzing the Effects of Short-term Volatility in Real Exchange Rates. Review of Economics and Statistics, 68, 311-315.

Kripfganz, S. and Schneider D.C. (2016). ARDL: Stata Module to Estimate Autoregressive Distributed Lag Models. [PowerPoint slides], Retrieved from:https://www.stata.com/meeting/chicago16/slides/chicago16_kripfganz.pdf

Kroner, K.F. and Lastrapes, W.D. (1993). The Impact of Exchange Rate Volatility on International Trade: Reduced Form Estimates Using The GARCH-In-Mean Model. Journal of International Money and Finance, 12, 298-318.

Mandelbrot, B.B. (1963). The Variation of Certain Speculative Prices. The Journal of Business, 36(4), 394-419.

McKenzie, M.D. (1998). The Impact of Exchange Rate Volatility on Australian Trade Flows. Journal of International Financial Markets, Institutions and Money, 8, 21-38.

McKenzie, M.D. and Brooks, R.D. (1997). The Impact of Exchange Rate Volatility on German-US Trade Flows. Journal of International Financial Markets, Institutions and Money, 7, 73-87.

Newey, W. K. and West, K.D. (1987). A Simple, Positive Semi-Definite, Heteroskedasticity and Autocorrelation Consistent Covariance Matrix. Econometrica, 55, 703-708.

Nicita, A. (2013). Exchange Rates, International Trade and Trade Policies. International Economics, 135$136,47-61$.

Perée, E. and Steinherr, A. (1989). Exchange Rate Uncertainty and Foreign Trade, European Economic Review, 33, 1241-1264.

Pagan, A and Ullah, A. (1988). The Econometric Analysis of Models with Risk Terms. Journal of Applied Econometrics, 3, 87-105. 
Pesaran, M. H. and Shin, Y. (1998). An Autoregressive Distributed-Lag Modelling Approach to Cointegration Analysis. In Econometrics and Economic Theory in the 20th Century. The Ragnar Frisch Centennial Symposium, ed. S. Strøm, chap. 11, 371-413. Cambridge: Cambridge University Press.

Pesaran, M.H., Shin, Y. and Smith, R.J. (2001). Bounds Testing Approaches to the Analysis of Level Relationships. Journal of Applied Econometrics, 16, 289-326.

Phillips, P. C. B. and Perron P. (1988). Testing For a Unit Root in Time Series Regression. Biometrika, 75: 335-346

Pozo, S. (1992). Conditional Exchange Rate Volatility and the Volume of International Trade: Evidence from the Early 1900s. Review of Economics and Statistics, 74(2), 325-329.

Rahmatsyah, T., Rajaguru, G. and Siregar, R.Y. (2002). Exchange-Rate Volatility, Trade and "Fixing for Life" In Thailand. Japan and World Economy, 14, 445-470.

Ramsey, J. B. (1969). Tests for Specification Errors in Classical Linear Least Squares Regression Analysis. Journal of the Royal Statistical Society, Series B., 31(2), 350-371

Rey, S. (2006). Effective Exchange Rate Volatility and MENA Countries' Exports to the EU. Journal of Economic Development, 31, 23-54.

Sauer, C. and Bohara, A.K. (2001). Exchange Rate Volatility and Exports: Regional Differences between Developing and Industrialized Countries. Review of International Economics, 9(1), 133-152.

Schwarz, G.E. (1978). Estimating the Dimension of a Model. Annals of Statistics, 6(2): 461-464

Shapiro, S. S. and Wilk M. B. (1965). An Analysis of Variance Test for Normality (Complete Samples). Biometrika, 52, 591-611.

Simsek, M. and Kadılar, C. (2006). Döviz Kurundaki Değişkenliğin Türkiye'nin İhracatına Uzun Dönemli Etkisi. Hacettepe Üniversitesi Iktisadi ve Idari Bilimler Fakültesi Dergisi, 24(1), 45-68.

Viaene, J.M. and De Vries, C.G. (1992). International Trade and Exchange Rate Volatility. European Economic Review, 36(6), 1311-1321.

Wang, K.L. and Barrett, C.B. (2007). Estimating the Effects of Exchange Rate Volatility on Export Volumes. Journal of Agricultural and Resource Economics, 32(2), 225-255.

Westerfield, J. (1977). An Examination of Foreign Exchange Risk under Fixed and Floating Rate Regimes. Journal of International Economics, 7(2), 181-200.

White, H. (1980). A Heteroskedasticity-Consistent Covariance Matrix Estimator and a Direct Test for Heteroskedasticity. Econometrica. 48 (4): 817-838

Wolf, A. (1995). Import and Hedging Uncertainty in International Trade. Journal of Futures Markets, 15, 101-110. 


\section{Appendix A}

Table A.1: Data and Data Sources

\begin{tabular}{|c|c|c|c|c|c|}
\hline & Period & Real Export ${ }^{a}(X)$ & $\begin{array}{l}\text { World Income } \\
\text { (W) }\end{array}$ & $\begin{array}{l}\text { Real Effective } \\
\text { Exchange Rate } \\
\text { (RER) }\end{array}$ & $\begin{array}{l}\text { Exchange Rate } \\
\text { Volatility (VOL) }\end{array}$ \\
\hline \multirow[b]{2}{*}{ Turkey } & \multirow{2}{*}{$\begin{array}{c}\text { 1998:Q1 } \\
- \\
\text { 2017:Q1 }\end{array}$} & $\begin{array}{l}\text { Nominal Export } \\
\text { (CBRT) }\end{array}$ & \multirow{12}{*}{$\begin{array}{l}\text { Index }(2010=100) \\
\text { of Gross Domestic } \\
\text { Production in } \\
\text { constant prices in } \\
\text { OECD countries as } \\
\text { proxy of real world } \\
\text { income } \\
\text { (FRED) }\end{array}$} & \multirow{2}{*}{$\begin{array}{l}\text { Real Effective } \\
\text { Exchange Rate Index } \\
(2010=100) \\
\quad \text { (FRED) }\end{array}$} & \multirow[b]{2}{*}{$\mathrm{ARCH}(1)$} \\
\hline & & $\begin{array}{l}\text { GDP Deflator } \\
(2010=100) \\
\text { (FRED) }\end{array}$ & & & \\
\hline \multirow[b]{2}{*}{ Mexico } & \multirow{2}{*}{$\begin{array}{c}\text { 1996:Q1 } \\
- \\
\text { 2017:Q1 }\end{array}$} & $\begin{array}{l}\text { Nominal Export } \\
\text { (FRED) }\end{array}$ & & \multirow{2}{*}{$\begin{array}{l}\text { Real Effective } \\
\text { Exchange Rate Index } \\
(2010=100) \\
\quad(\text { FRED) }\end{array}$} & \multirow[b]{2}{*}{$\begin{array}{c}\text { MSSD } \\
\text { (8 Quarters) }\end{array}$} \\
\hline & & $\begin{array}{l}\text { GDP Deflator } \\
(2010=100) \\
\text { (FRED) }\end{array}$ & & & \\
\hline \multirow[b]{2}{*}{ Indonesia } & \multirow{2}{*}{$\begin{array}{c}\text { 2000:Q1 } \\
- \\
\text { 2017:Q1 }\end{array}$} & $\begin{array}{l}\text { Nominal Export } \\
\text { (FRED) }\end{array}$ & & \multirow{2}{*}{$\begin{array}{l}\text { Real Effective } \\
\text { Exchange Rate Index } \\
(2010=100) \\
\text { (FRED) }\end{array}$} & \multirow[b]{2}{*}{ GARCH $(1,1)$} \\
\hline & & $\begin{array}{l}\text { GDP Deflator } \\
(2010=100) \\
\text { (FRED) }\end{array}$ & & & \\
\hline \multirow[b]{2}{*}{ Brazil } & \multirow{2}{*}{$\begin{array}{c}\text { 1996:Q1 } \\
- \\
\text { 2017:Q1 }\end{array}$} & $\begin{array}{l}\text { Nominal Export } \\
\text { (FRED) }\end{array}$ & & \multirow{2}{*}{$\begin{array}{l}\text { Real Effective } \\
\text { Exchange Rate Index } \\
(2010=100) \\
\text { (FRED) }\end{array}$} & \multirow[b]{2}{*}{$\begin{array}{c}\text { MSSD } \\
\text { (8 Quarters) }\end{array}$} \\
\hline & & $\begin{array}{c}\text { GDP Deflator } \\
(2010=100) \\
\text { (FRED) }\end{array}$ & & & \\
\hline \multirow[b]{2}{*}{ Poland } & \multirow{2}{*}{$\begin{array}{c}\text { 2002:Q1 } \\
- \\
\text { 2017:Q1 }\end{array}$} & $\begin{array}{l}\text { Nominal Export } \\
\text { (FRED) }\end{array}$ & & \multirow{2}{*}{$\begin{array}{l}\text { Real Effective } \\
\text { Exchange } \quad \text { Rate } \\
\text { Index }(2010=100) \\
\text { (FRED) }\end{array}$} & \multirow[b]{2}{*}{$\operatorname{GARCH}(1,2)$} \\
\hline & & $\begin{array}{l}\text { GDP Deflator } \\
(2010=100) \\
\text { (FRED) }\end{array}$ & & & \\
\hline \multirow[b]{2}{*}{ Chile } & \multirow{2}{*}{$\begin{array}{c}\text { 2000:Q1 } \\
- \\
\text { 2017:Q1 }\end{array}$} & $\begin{array}{l}\text { Nominal Export } \\
\text { (FRED) }\end{array}$ & & \multirow{2}{*}{\begin{tabular}{l} 
Real $\quad$ Effective \\
Exchange Rate \\
Index $(2010=100)$ \\
\multicolumn{1}{c}{$($ FRED $)$}
\end{tabular}} & \multirow[b]{2}{*}{$\begin{array}{c}\text { MSSD } \\
\text { (8 Quarters) }\end{array}$} \\
\hline & & $\begin{array}{c}\text { Consumer Price } \\
\text { Index } \\
(2010=100) \\
\text { (FRED) }\end{array}$ & & & \\
\hline
\end{tabular}

Note: ${ }^{a}$ Nominal export is deflated by GDP Deflator $(2010=100)$ (if available) to obtain real exports for each country. CBRT and FRED are abbreviations of the Central Bank of the Republic of Turkey and Federal Reserve Economic Data, respectively.

${ }^{b}$ I use index of total gross domestic production in constant prices for the OECD total area in line with the literature. 
Table A.2: ADF Unit Root Test Results for RER

\begin{tabular}{|c|c|c|c|c|}
\hline & Trend and Constant & Constant & None & \multirow[b]{2}{*}{$\begin{array}{l}\text { Number } \\
\text { of Lags }\end{array}$} \\
\hline & $\begin{array}{l}\text { Test Statistic } \\
\text { (Critical Value) }\end{array}$ & $\begin{array}{c}\text { Test Statistic } \\
\text { (Critical Value) }\end{array}$ & $\begin{array}{c}\text { Test Statistic } \\
\text { (Critical Value) }\end{array}$ & \\
\hline Turkey & $\begin{array}{c}-2.738 \\
(-3.474)\end{array}$ & $\begin{array}{c}-2.891 \\
(-2.909)\end{array}$ & $\begin{array}{c}-0.068 \\
(-1.950)\end{array}$ & 1 \\
\hline Indonesia & $\begin{array}{c}-3.205 \\
(-3.484)\end{array}$ & $\begin{array}{c}-2.370 \\
(-2.917)\end{array}$ & $\begin{array}{c}-0.072 \\
(-1.950)\end{array}$ & 2 \\
\hline Brazil & $\begin{array}{c}-2.179 \\
(-3.468)\end{array}$ & $\begin{array}{c}-1.888 \\
(-2.904)\end{array}$ & $\begin{array}{c}-0.298 \\
(-1.950)\end{array}$ & 2 \\
\hline Mexico & $\begin{array}{c}-2.822 \\
(-3.467)\end{array}$ & $\begin{array}{c}-1.659 \\
(-2.904)\end{array}$ & $\begin{array}{c}-0.128 \\
(-1.950)\end{array}$ & 1 \\
\hline Poland & $\begin{array}{c}-2.120 \\
(-3.493) \\
\end{array}$ & $\begin{array}{c}-2.088 \\
(-2.924) \\
\end{array}$ & $\begin{array}{c}-0.065 \\
(-1.950) \\
\end{array}$ & 3 \\
\hline Chile & $\begin{array}{c}-2.619 \\
(-3.467)\end{array}$ & $\begin{array}{c}-2.547 \\
(-2.904)\end{array}$ & $\begin{array}{c}-0.336 \\
(-1.950) \\
\end{array}$ & 1 \\
\hline
\end{tabular}

Note: The null hypothesis of the ADF test is that a variable contains a unit root. Number of lags are specified by SBIC. Critical values in the parentheses are given at five percent significance level.

Table A.3: Phillips-Perron Unit Root Test Results for RER

\begin{tabular}{|c|c|c|c|c|}
\hline & Trend and Constant & Constant & None & Number of \\
\hline & $\begin{array}{c}\text { Test Statistic } \\
\text { (Critical Value) }\end{array}$ & $\begin{array}{c}\text { Test Statistic } \\
\text { (Critical Value) }\end{array}$ & $\begin{array}{c}\text { Test Statistic } \\
\text { (Critical Value) }\end{array}$ & $\begin{array}{c}\text { Newey- } \\
\text { West Lags }\end{array}$ \\
\hline Turkey & $\begin{array}{c}-2.338 \\
(-3.473)\end{array}$ & $\begin{array}{c}-2.604 \\
(-2.908)\end{array}$ & $\begin{array}{c}-0.152 \\
(-1.950)\end{array}$ & 3 \\
\hline Indonesia & $\begin{array}{c}-3.268 \\
(-3.482)\end{array}$ & $\begin{array}{c}-2.773 \\
(-2.916)\end{array}$ & $\begin{array}{c}-0.341 \\
(-1.950)\end{array}$ & 3 \\
\hline Brazil & $\begin{array}{c}-2.086 \\
(-3.466)\end{array}$ & $\begin{array}{c}-1.868 \\
(-2.903)\end{array}$ & $\begin{array}{c}-0.298 \\
(-1.950)\end{array}$ & 3 \\
\hline Mexico & $\begin{array}{c}-2.763 \\
(-3.466)\end{array}$ & $\begin{array}{c}-1.692 \\
(-2.903)\end{array}$ & $\begin{array}{c}-0.078 \\
(-1.950)\end{array}$ & 3 \\
\hline Poland & $\begin{array}{c}-2.535 \\
(-3.490)\end{array}$ & $\begin{array}{c}-2.547 \\
(-2.922)\end{array}$ & $\begin{array}{c}-0.362 \\
(-1.950)\end{array}$ & 3 \\
\hline Chile & $\begin{array}{c}-2.343 \\
(-3.466)\end{array}$ & $\begin{array}{c}-2.283 \\
(-2.903)\end{array}$ & $\begin{array}{c}-0.379 \\
(-1.950)\end{array}$ & 3 \\
\hline
\end{tabular}

Note: The null hypothesis of the Phillips-Perron (1988) test is that a variable contains a unit root. Test employs Newey-West (1987) standard errors to account for serial correlation. Critical values in the parentheses are given at five percent significance level. Selected Newey-West lag length is three. 
International Journal of Economic and Administrative Studies 